PLENUM: THE NATURE OF SCIENCE

\section{PHARMACEUTICAL RESEARCH}

\section{Journal of the}

\section{Pharmaceutical-Biomedical} Sciences

\section{Editor: Wolfgang Sadée}

The latest addition to Plenum's roster of journals, Pharmaceutical Research presents new developments in many fast-breaking areas.

Subscription: Volume 3, 1986 (6 issues) Institutional rate: $\$ 89.50$ in US $/ \$ 102.00$ elsewhere Personal rate: $\$ 45.00$ in US/ $\$ 53.00$ elsewhere

\section{Now published by Plenum for the Biochemical Society BIOSCIENCE REPORTS}

Editorial Chairman:

\section{A. Pasternak}

Deputy Chairman:

William J. Lennarz

This monthly journal offers rapid publication of high-quality papers in the areas of molecular and cellular biology.

Subscription: Volume 6, 1986 (12 issues) $\$ 215.00$

\section{Forthcoming \\ SELF-ORGANIZING SYSTEMS}

\section{The Emergence of Order} edited by F. Eugene Yates

Offers a rich diversity of perspectives on the emergence of natural order within a variety of natural systems. A volume in the series Life Science Monographs.

0-306-42145-3/approx. 675 pp./ill./1986

\section{GENETIC ENGINEERING OF ANIMALS}

\section{An Agricultural Perspective}

edited by $\mathbf{J}$. Warren Evans and Alexander Hollaender

0-306-42238-7/proceedings 336 pp./ill./1986

$\$ 49.50$ (\$59.40 outside US \& Canada) text adoption price on orders of six or more copies: $\$ 32.50$

VISIT PLENUM AT BOOTHS B16 AND B18 AT FASEB!

Plenum Publishing Corporation 233 Spring Street

New York, N.Y. 10013

In the United Kingdom:

88/90 Middlesex Street

London E1 7EZ, England

example Marr's work on vision) it may be possible to separate a computational theory of why particular procedures should be performed from an algorithmic theory of how they are performed. This separation is possible because the properties of the real world form part of the justification for why certain procedures are necessary. Our visual systems may have evolved the way they are partly because objects tend to be rigid, show certain symmetries and so on. But there is no comparable external evolutionary pressure for UG to possess certain properties (this point is explicitly acknowledged by Chomsky, p.274, note 22 ). Only the constraints on the biological manifestation of UG are relevant, and this manifestation, I have suggested above, may be partially redundant and repetitious. This leaves the linguist's version of UG as an unmotivated abstraction, the very thing that Chomsky has been working against. The question is, is it only the child in the Papua New Guinean village who has no clothes?

Philip T. Smith is Reader in the Department of Psychology, University of Reading, Whiteknights, Reading RG6 $2 A L, U K$.

\section{On the paper chase}

\section{John Galloway}

Elements of the Scientific Paper: A Stepby-Step Guide for Students and Professionals. By Michael J. Katz. Yale University Press: 1986. Pp.130. Hbk \$25, £18; $p b k \$ 8.50, £ 5.95$.

SCIENCE must now be one of the world's largest industries. What it manufactures, of course, is knowledge and like other goods this knowledge has to be sold. The way this is done is by the publication of the papers that make up the scientific literature. Unlike most industries, however, production and sales are the responsibility of the same person - the scientist; and when it comes to writing papers the average scientist does not do it all that well, the tendency at the moment being to write in the inert prose of a sort of machine code.

Scientists, then, are in need of all the help they can get. In response, a new industry has arisen, that of telling them how to write. Some thirty books can readily be found in this genre, to which we must now add yet another. Professor Katz takes us through one of his own papers - on axonal growth - section by section with tips along the way for avoiding some of the loose usage of English which is characteristic of the scientific paper. This is a worthy enough aim, although if you want to know how to use English, Fowler tells you more fully, Mark Twain more wittily.

Even so, it would be churlish not to wish well an attempt to get scientists to be clearer in their writing. On the other hand, at the back of my own mind when writing papers was the aphorism "if your thoughts are rubbish merely, be certain not to write too clearly". From the evidence of the large proportion of papers that are cryptic when they are not incomprehensible, that feeling is not uncommon.

For a non-scientist the book would, I think, merely reinforce the notion that the acquisition of scientific knowledge and understanding is somewhat mechanical. I don't think that Sir Peter Medawar's "Is the Scientific Paper a Fraud", with its exhortation to scientists to tell the truth about their thought processes, had that much influence. For example, few people would get away with Francis Crick's "I first learned of it [the new idea] sitting round a campfire in Aspen, Colorado" in a paper in Trends in Neurosciences. I sat up, though, at Professor Katz's suggestion that any results that don't fit should be put in a drawer and forgotten; everyone does it, but it's supposed to be a secret.

Professor Katz also tells us that a paper should be like a detective novel and, elsewhere in the book, that it is like a poem (that is, with a well defined form). These are nice analogies. The poetical form should of course mimic the limerick which, as Clifton Fadiman said, possesses progression, development, variety, speed, climax - and a high mnemonic value. Above all a paper, like an advertisement, has to be remembered.

John Galloway, 54 Windmill Drive, Croxley Green, Hertfordshire WD3 $3 F E$, UK, is a science administrator. 